\title{
STUDIES OF RESPIRATORY PHYSIOLOGY IN CHILDREN. VI. LUNG DIFFUSING CAPACITY, DIFFUSING CAPACITY OF THE PULMONARY MEMBRANE AND PULMONARY CAPILLARY BLOOD VOLUME IN CONGENITAL HEART DISEASE *
}

\author{
By GIOVANNI BUCCI AND CHARLES D. COOK WITH THE TECHNICAL ASSISTANCE OF \\ JOANNA F. HAMANN
}

\author{
(From the Department of Pediatrics, Harvard Medical School, and the Department of Medicine \\ of the Children's Hospital Medical Center, Boston, Mass.)
}

(Submitted for publication January 12, 1961 ; accepted April 13, 1961)

Studies of lung diffusing capacity for carbon monoxide $\left(\mathrm{DL}_{\mathrm{CO}}\right)$ at various alveolar $\mathrm{O}_{2}$ tensions $(1,2)$ and on the kinetics of the carboxyhemoglobin reaction $(3,4)$ have made possible the calculation of the diffusing capacity of the pulmonary membrane (DM) and the pulmonary capillary blood volume $\left(\mathrm{V}_{\mathrm{c}}\right)$ (5). In the present study $\mathrm{DL}_{\mathrm{CO}}$, $\mathrm{DM}$ and $\mathrm{V}_{\mathrm{c}}$ have been determined in $34 \mathrm{pa}-$ tients with various types of congenital heart disease, compared to previous studies in normal controls (6) and related to hemodynamic data derived from cardiac catheterizations. The effect of exercise on the pulmonary capillary bed of one patient with a left-to-right shunt has been studied, and in ten patients carbon monoxide diffusion studies have been repeated after surgical correction of the cardiac malformation.

\section{SUBJECTS AND METHODS ${ }^{1}$}

Although the patients ranged in age from 8 to 42 years, most were children, only 5 of them being over 18 years. None of the patients had any known primary pulmonary abnormalities and none had clinical signs of congestive heart failure. Cardiac diagnoses were established by the usual criteria including cardiac catheteri-

\footnotetext{
* Supported by Grants E-1170 and H5339 from the National Institutes of Health, Public Health Service, Bethesda, Md.

1 Abbreviations used in this paper are: $\mathrm{DL}_{\mathrm{co}}=$ total lung diffusing capacity for carbon monoxide $(\mathrm{ml} / \mathrm{mm} \mathrm{Hg}$ / $\min )$; $\mathrm{DM}_{\mathrm{M}}=$ diffusing capacity of the pulmonary membrane $(\mathrm{ml} / \mathrm{mm} \mathrm{Hg} / \mathrm{min}) ; \quad \mathrm{V}_{\mathrm{c}}=$ pulmonary capillary blood volume $(\mathrm{ml}) ; \mathrm{RM}_{\mathrm{M}} / \mathrm{R}_{\mathrm{c}}=$ the ratio of the membrane to intracapillary resistance to diffusion; $\dot{Q}_{P}=$ pulmonary blood flow $\left(\mathrm{L} / \mathrm{min} / \mathrm{m}^{2}\right.$ BSA $) ; \overline{\mathrm{P}} \mathrm{c}_{\mathrm{O}_{2}}=$ mean capillary oxygen tension $(\mathrm{mm} \mathrm{Hg})$; TLC $=$ total lung capacity (L); ASD = atrial septal defect ; VSD = ventricular septal defect; $\mathrm{PS}=$ pulmonic stenosis $; \mathrm{TOF}=$ tetralogy of Fallot.
}

zation $(7)^{2}$ (in all but Patient 15). The diagnosis was confirmed at operation in 28 of the 34 cases including Patients 15 and 21. In Patient 20 the diagnosis of a hypoplastic left heart was established at autopsy. Only pulmonary blood flows and mean pulmonary artery wedge pressures obtained within 20 days of the diffusion study were used for examining the relations of these factors to $\mathrm{DM}_{\mathrm{M}}$ and $\mathrm{V}_{\mathrm{c}}$.

The pertinent clinical and laboratory data for the individual patients are given in Tables I and II. The patients are grouped partly according to diagnosis and partly according to their hemodynamic status. In group I are 24 patients with increased pulmonary blood flow $\left(Q_{P}\right)$. Of the 21 patients with atrial septal defect (ASD), the ostium secundum type was an isolated lesion in 13 , associated with partial anomalous pulmonary venous return in 3 and with mild pulmonic stenosis in 1 . Two patients had an ostium primum septal defect and associated significant mitral regurgitation. In Patients 20 and 21, conditions (a hypoplastic left heart and pericarditis, respectively) apt to produce increased pulmonary venous pressure were associated with the ASD. Three patients with ventricular septal defect (VSD) are included in this group with increased $\dot{Q}_{\mathrm{P}}$.

Six patients with normal or decreased $Q_{P}$ make up group II. Four of these had pulmonic stenosis (PS), one had tetralogy of Fallot (TOF) and one had tricuspid atresia. In group III are four cases with congenital or acquired aorto-pulmonary shunts and other associated conditions. These patients are separated because their $\dot{Q}_{P}$ status had varied with surgery or acquired pulmonary vascular changes.

Lung volumes were determined in duplicate by means of a spirometer and a closed circuit helium dilution method (8). DL co's at high and low $\mathrm{O}_{2}$ concentrations ( 90 and 21 per cent, respectively, for the inspired gas mixture) were obtained from the 10-second breath-holding technique described by Forster and co-workers $(9,10)$ and stand-

2 Cardiac catheterizations were performed in the cardiopulmonary laboratory of the Children's Hospital Medical Center; we are indebted to Drs. A. S. Nadas and A. M. Rudolph for the opportunity to study the patients and permission to use the catheterization data. 
TABLE I

Clinical and pulmonary function data in patients with congenital heart disease

\begin{tabular}{|c|c|c|c|c|c|c|c|c|c|c|}
\hline $\begin{array}{l}\text { Patient } \\
\text { no. }\end{array}$ & Diagnosis & Sex & Age & $\mathrm{Ht}$ & Wt & BSA & TLC & Dlco & Dм & $\mathrm{V}_{\mathrm{o}}$ \\
\hline & & & $\begin{array}{l}\text { yrs } \\
\text { Sroup }\end{array}$ & $\mathrm{cm}$ & $k g$ & $m^{2}$ & $L$ & \multicolumn{2}{|c|}{$\mathrm{ml} / \mathrm{mm} \mathrm{Hg} / \mathrm{min}$} & $m l$ \\
\hline $\begin{array}{r}1 \\
2 \\
3 \\
4 \\
5 \\
6 \\
7 \\
8 \\
9 \\
10 \\
11 \\
12 \\
13\end{array}$ & $\begin{array}{l}\text { ASD } \\
\text { ASD } \\
\text { ASD } \\
\text { ASD } \\
\text { ASD } \\
\text { ASD } \\
\text { ASD } \\
\text { ASD } \\
\text { ASD } \\
\text { ASD } \\
\text { ASD } \\
\text { ASD } \\
\text { ASD }\end{array}$ & $\begin{array}{l}\mathrm{M} \\
\mathrm{F} \\
\mathrm{F} \\
\mathrm{F} \\
\mathrm{M} \\
\mathrm{M} \\
\mathrm{F} \\
\mathrm{M} \\
\mathrm{F} \\
\mathrm{M} \\
\mathrm{F} \\
\mathrm{M} \\
\mathrm{F}\end{array}$ & $\begin{array}{r}9 \\
9 \\
10 \\
12 \\
14 \\
14 \\
15 \\
16 \\
16 \\
17 \\
18 \\
26 \\
35\end{array}$ & $\begin{array}{l}128 \\
125 \\
132 \\
150 \\
156 \\
164 \\
147 \\
168 \\
165 \\
175 \\
163 \\
178 \\
163\end{array}$ & $\begin{array}{l}24 \\
21 \\
25 \\
38 \\
48 \\
55 \\
38 \\
44 \\
55 \\
53 \\
57 \\
79 \\
49\end{array}$ & $\begin{array}{l}0.91 \\
0.85 \\
0.96 \\
1.27 \\
1.40 \\
1.58 \\
1.25 \\
1.46 \\
1.58 \\
1.63 \\
1.58 \\
1.98 \\
1.46\end{array}$ & $\begin{array}{l}2.26 \\
2.05 \\
2.36 \\
2.84 \\
3.94 \\
4.53 \\
2.28 \\
4.12 \\
4.65 \\
5.93 \\
4.37 \\
6.89 \\
4.30\end{array}$ & $\begin{array}{l}19.3 \\
15.3 \\
21.3 \\
22.0 \\
26.7 \\
27.5 \\
23.0 \\
41.5 \\
32.1 \\
41.8 \\
32.0 \\
47.7 \\
27.6\end{array}$ & $\begin{array}{l}37 \\
30 \\
42 \\
49 \\
64 \\
55 \\
51 \\
81 \\
62 \\
96 \\
63 \\
86 \\
77\end{array}$ & $\begin{array}{r}61 \\
47 \\
71 \\
61 \\
60 \\
83 \\
65 \\
123 \\
97 \\
112 \\
110 \\
151 \\
83\end{array}$ \\
\hline 14 & ASD) & $\mathrm{F}$ & 8 & 130 & 24 & 0.93 & 2.51 & 19.5 & 43 & 49 \\
\hline 15 & ASD $\left\{\begin{array}{c}\text { partial anomalous pulmonary } \\
\text { venous return }\end{array}\right.$ & M & 10 & 136 & 28 & 1.02 & 2.89 & 20.1 & 48 & 55 \\
\hline 16 & ASD & $\mathrm{F}$ & 18 & 154 & 63 & 1.50 & 4.36 & 32.0 & 70 & 89 \\
\hline 17 & ASD, mild pulmonic stenosis & M & 8 & 129 & 25 & 0.93 & 2.22 & 23.0 & 46 & 74 \\
\hline $\begin{array}{l}18 \\
19\end{array}$ & $\begin{array}{l}\text { ASD, mitral regurg. } \\
\text { ASD, mitral and tricuspid regurg. }\end{array}$ & $\begin{array}{l}\mathrm{M} \\
\mathrm{M}\end{array}$ & $\begin{array}{l}12 \\
15\end{array}$ & $\begin{array}{l}150 \\
170\end{array}$ & $\begin{array}{l}46 \\
59\end{array}$ & $\begin{array}{l}1.40 \\
1.68\end{array}$ & $\begin{array}{l}3.30 \\
4.90\end{array}$ & $\begin{array}{l}22.9 \\
43.0\end{array}$ & $\begin{array}{l}35 \\
94\end{array}$ & $\begin{array}{l}129 \\
119\end{array}$ \\
\hline $\begin{array}{l}20 \\
21\end{array}$ & $\begin{array}{l}\text { ASD, hypoplastic left heart } \\
\text { ASD, pericarditis }\end{array}$ & $\begin{array}{l}\mathrm{F} \\
\mathrm{M}\end{array}$ & $\begin{array}{l}16 \\
42\end{array}$ & $\begin{array}{l}151 \\
173\end{array}$ & $\begin{array}{l}40 \\
76\end{array}$ & $\begin{array}{l}1.31 \\
1.90\end{array}$ & $\begin{array}{l}2.49 \\
4.70\end{array}$ & $\begin{array}{l}25.4 \\
32.4\end{array}$ & $\begin{array}{l}45 \\
54\end{array}$ & $\begin{array}{r}98 \\
114\end{array}$ \\
\hline $\begin{array}{l}22 \\
23 \\
24\end{array}$ & $\begin{array}{l}\text { VSD } \\
\text { VSD, mild pulmonic stenosis } \\
\text { VSD, pulmonary vascular } \\
\text { obstruction }\end{array}$ & $\begin{array}{l}\mathrm{M} \\
\mathrm{F} \\
\mathrm{M}\end{array}$ & $\begin{array}{r}11 \\
11 \\
9 \\
\text { roup }\end{array}$ & $\begin{array}{l}145 \\
130 \\
139\end{array}$ & $\begin{array}{l}32 \\
22 \\
23\end{array}$ & $\begin{array}{l}1.14 \\
0.90 \\
0.96\end{array}$ & $\begin{array}{l}3.17 \\
1.84 \\
2.31\end{array}$ & $\begin{array}{l}23.3 \\
12.6 \\
18.3\end{array}$ & $\begin{array}{l}48 \\
26 \\
30\end{array}$ & $\begin{array}{l}73 \\
38 \\
69\end{array}$ \\
\hline $\begin{array}{l}25 \\
26 \\
27 \\
28 \\
29 \\
30\end{array}$ & $\begin{array}{l}\text { Pulmonic stenosis, moderate } \\
\text { Pulmonic stenosis, severe } \\
\text { Pulmonic stenosis, severe } \\
\text { Pulmonic stenosis, moderate } \\
\text { Tetral. of Fallot } \\
\text { Tricuspid atresia }\end{array}$ & $\begin{array}{l}\mathrm{M} \\
\mathrm{M} \\
\mathrm{M} \\
\mathrm{M} \\
\mathrm{M} \\
\mathrm{M}\end{array}$ & $\begin{array}{l}9 \\
11 \\
11 \\
12 \\
11 \\
19\end{array}$ & $\begin{array}{l}122 \\
142 \\
134 \\
152 \\
128 \\
175\end{array}$ & $\begin{array}{l}22 \\
28 \\
25 \\
41 \\
24 \\
55\end{array}$ & $\begin{array}{l}0.86 \\
1.06 \\
0.96 \\
1.32 \\
0.96 \\
1.65\end{array}$ & $\begin{array}{l}2.24 \\
2.95 \\
2.71 \\
3.31 \\
2.50 \\
4.97\end{array}$ & $\begin{array}{l}15.2 \\
13.1 \\
14.8 \\
20.7 \\
10.0 \\
42.7\end{array}$ & $\begin{array}{l}35 \\
26 \\
34 \\
47 \\
19 \\
81\end{array}$ & $\begin{array}{l}37 \\
34 \\
35 \\
52 \\
28 \\
82\end{array}$ \\
\hline \multicolumn{11}{|c|}{ Group III } \\
\hline 31 & $\begin{array}{l}\text { Tetral. of Fallot, Pott's proced. } \\
4 \text { yrs previously }\end{array}$ & $\mathrm{F}$ & 12 & 129 & 21 & 0.94 & 1.99 & 15.6 & 29 & 50 \\
\hline 32 & $\begin{array}{l}\text { Tetral. of Fallot, Pott's proced. } \\
6 \text { yrs previously }\end{array}$ & M & 15 & 155 & 68 & 1.44 & 3.84 & 24.4 & 48 & 73 \\
\hline 33 & $\begin{array}{l}\text { Tetral. of Fallot, Pott's proced. } \\
6 \text { yrs previously; pulmonary vas- } \\
\text { cular obstruction }\end{array}$ & M & 33 & 164 & 56 & 1.61 & 3.66 & 23.0 & 41 & 58 \\
\hline 34 & $\begin{array}{l}\text { Patent ductus arteriosus, pulmo- } \\
\text { nary vascular obstruction }\end{array}$ & $\mathbf{M}$ & 17 & 171 & 52 & 1.59 & 5.53 & 27.2 & 63 & 60 \\
\hline
\end{tabular}

ardized by Ogilvie, Forster, Blakemore and Morton (11). A small but significant and progressive decrease in Dlco during successive determinations at both high and low $\mathrm{O}_{2}$ tensions was found in the patients with congenital heart disease. Carbon monoxide accumulation could not have been enough to account for this (9). Corresponding variations in alveolar volume, breath-holding time or possible systematic errors in gas analysis have not been detected, and since a very similar pattern was observed in the normal controls (6), no correction was made for this variation. The calculations of $D_{M}$, $\mathrm{V}_{\mathrm{c}}{ }^{3}$ and the ratio of membrane to intracapillary re-

3 These relations are shown by the equation:

$$
1 / \mathrm{D}_{\mathrm{co}}=1 / \mathrm{DM}_{\mathrm{M}}+1 / \theta \mathrm{V}_{\mathrm{c}}
$$

where $\theta$ is a constant related to the rate of uptake of $\mathrm{CO}$ by hemoglobin at various $\mathrm{O}_{2}$ concentrations (3-5). 
MEASUREMENT OF LUNG DIFFUSING CAPACITY IN CONGENITAL HEART DISEASE

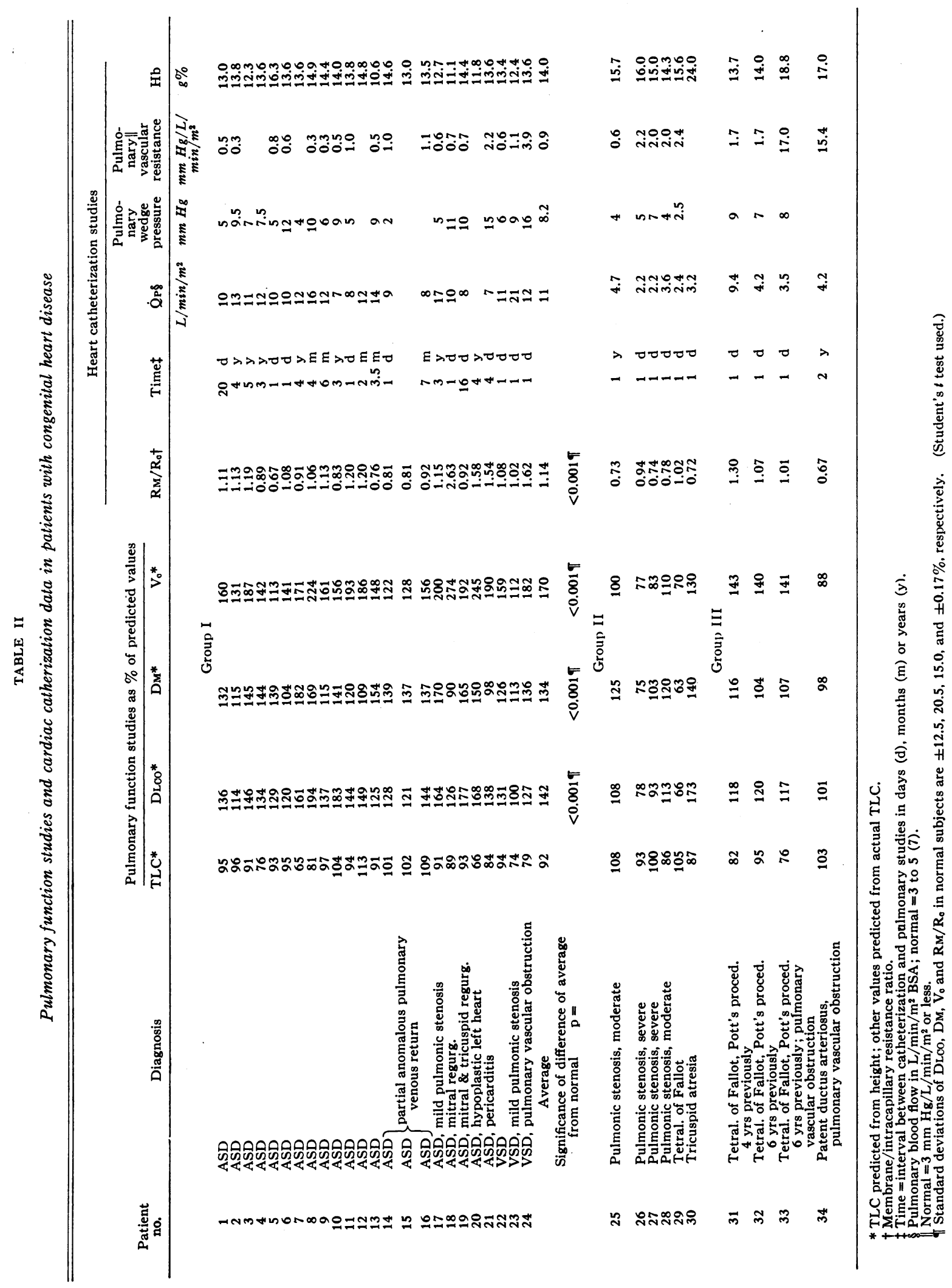




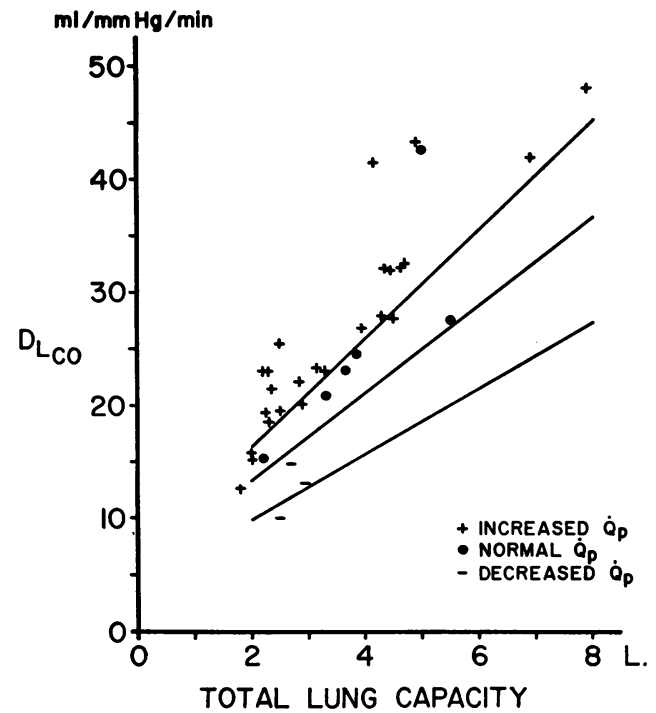

Fig. 1. Lung diffusion (Dlco) vs tOtal LUNG CAPACITY IN 34 PATIENTS WITH CONGENITAL HEART DISEASE. The three lines represent the average and 2 standard deviations around the average for normal subjects (6). Pulmonary blood flow $\left(\dot{Q}_{\mathrm{P}}\right)$ was considered increased if more than $5 \mathrm{~L} / \mathrm{min} / \mathrm{m}^{2}$ and decreased if less than 3 $\mathrm{L} / \mathrm{min} / \mathrm{m}^{2}$. Twenty of the 25 patients with increased $Q_{\mathbf{P}}$ have a significantly elevated $\mathrm{DL}_{\mathrm{co}}$.

sistance to diffusion $\left(\mathrm{R}_{\mathrm{M}} / \mathrm{R}_{\mathrm{c}}\right)^{4}$ followed the methods and equations of Roughton and Forster (5) and of McNeill, Rankin and Forster (12). More details of the corrections and calculations employed are given in a previous paper (6).

Since it has been previously shown that diffusion studies in normal children and adults correlate well with TLC (6), this parameter was used as a basis for prediction of the expected values for the patients. The individual determinations have been expressed as per cent of the predicted values. Similar comparisons were made using surface area as a basis for prediction; the changes were slightly smaller, but in the same direction and are not reported. TLC values were compared on the basis of height to our normal standards except that normal values for adult men were derived from the data of Hepper, Fowler and Helmholz (13).

In the cardiac patients, the SE of DLco determined in triplicate was \pm 1 per cent. Repeated determinations in one normal subject of $\mathrm{DM}_{\mathrm{M}}$ and $\mathrm{V}_{c}$, when based on three $\mathrm{DL}_{\mathrm{Co}}$ determinations at both high and low $\mathrm{O}_{2}$ concentrations, had SD's of \pm 17 and \pm 8 per cent, respectively. In one previously reported adult patient (6) with atrial septal defect and an elevated total lung diffusing capacity, similar variations in the $D_{M}$ and $V_{c}$ values were found.

$4 \mathrm{RM} / \mathrm{R}_{\mathrm{c}}=\mathrm{DL}_{\mathrm{Co}} / \mathrm{DM}_{\mathrm{M}}-\mathrm{DL}_{\mathrm{co}} \times 14.9 / \mathrm{Hb}(\mathrm{g} \%)$ where $\mathrm{DL}_{\mathrm{Co}}$ is the estimated diffusing capacity at $120 \mathrm{~mm} \mathrm{Hg}$ $\mathrm{Pc}_{0 .}$.
For the predicted values of $\mathrm{DL}_{\mathrm{co}}, \mathrm{DM}_{\mathrm{M}}$ and $\mathrm{V}_{c}, 2 \mathrm{SD}$ 's around the mean values averaged $\pm 25,41$ and 30 per cent, respectively. Two SD's around the mean predicted value for TLC averaged \pm 27 per cent.

For the exercise studies a bicycle ergometer 5 was used; the subjects were in the sitting position for this and all pulmonary tests. Since a steady circulatory state (14) and a steady DLco (15) are apparently reached after 2 minutes of exercise, all measurements of diffusion were performed at the beginning of the third minute of cycling. A moderate work load corresponding to a cardiac rate of 139 to 153 beats per minute was selected (16). The alveolar $\mathrm{CO}_{2}$ and $\mathrm{O}_{2}$ concentrations at the beginning and end of breath-holding and the $\mathrm{O}_{2}$ consumption during exercise were also determined and used for the calculation of $\mathrm{DLco}_{\mathrm{co}}$ at $120 \mathrm{~mm} \mathrm{Hg} \mathrm{Pc}_{\mathrm{O}_{2}}$ and for the corrected $1 / \theta$ values.

\section{RESULTS}

The results of the studies are shown in Tables I and II. As indicated in Figures 1,2 and 3, where individual values for $\mathrm{DL}_{\mathrm{co}}, \mathrm{DM}_{\mathrm{M}}$ and $\mathrm{V}_{\mathrm{c}}$ are plotted against TLC and compared with the normal ranges previously reported (6), these values average significantly $(\mathrm{p}<0.001)$ above normal in patients with an elevated $\dot{Q}_{\mathbf{P}}$ and in the normal

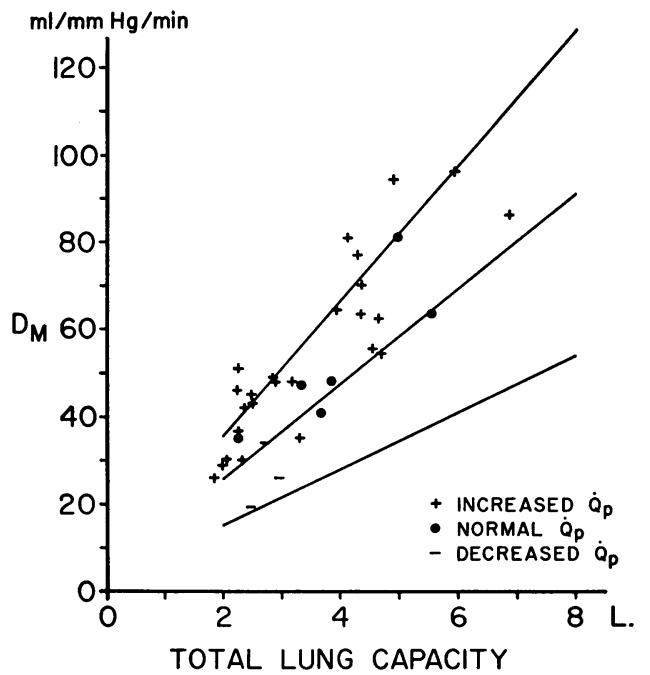

Fig. 2. Membrane diffusion (DM) vs total LUNG CAPACITY IN 34 PATIENTS WITH CONGENITAL HEART DISEASE. The three lines represent the average and 2 standard deviations around the average for normal subjects (6). Pulmonary blood flow $\left(Q_{P}\right)$ was considered increased if more than $5 \mathrm{~L} / \mathrm{min} / \mathrm{m}^{2}$ and decreased if less than $3 \mathrm{~L} / \mathrm{min} / \mathrm{m}^{2}$. Eight of the 25 patients with increased $\dot{Q}_{\mathrm{P}}$ have a significantly elevated DM.

${ }^{5}$ Elema Ergometer, Stockholm, Sweden. 


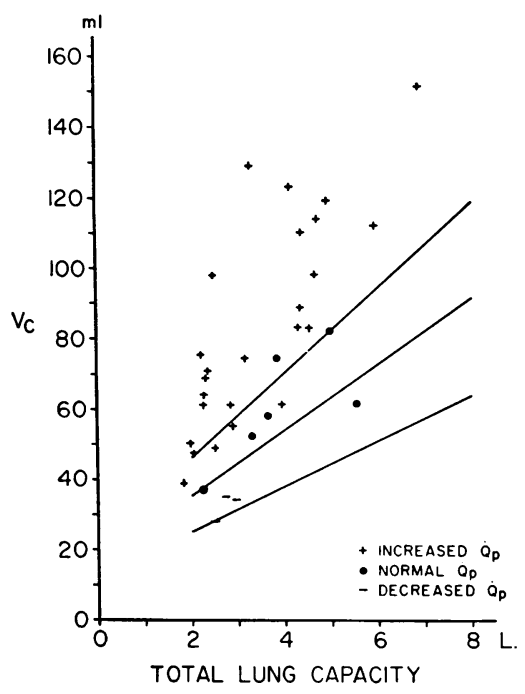

Fig. 3. Pulmonary capillary blood volume $\left(\mathrm{V}_{\mathbf{c}}\right)$ vS TOTAL LUNG CAPACITY IN 34 PATIENTS WITH CONGENITAL HEART DISEASE. The three lines represent the average and 2 standard deviations around the average for normal subjects (6). Pulmonary blood flow $\left(\dot{Q}_{\mathrm{P}}\right)$ was considered increased if more than $5 \mathrm{~L} / \mathrm{min} / \mathrm{m}^{2}$ and decreased if less than $3 \mathrm{~L} / \mathrm{min} / \mathrm{m}^{2}$. Twenty-one of the 25 patients with increased $\dot{Q}_{\mathbf{P}}$ have a significantly elevated $\mathrm{V}_{\mathrm{c}}$. range in patients with normal ${ }^{6}$ or low $\dot{Q}_{\mathbf{P}}$. In addition, irrespective of $\dot{Q}_{\mathbf{P}}$, all patients in whom a tetralogy of Fallot malformation had been treated with a Pott's anastomosis had an elevated $\mathrm{V}_{\mathrm{c}}$; Patient 34 with a patent ductus arteriosus and pulmonary vascular obstruction of long duration had low normal values. Within the group of patients with increased $Q_{\mathbf{P}}$ no correlation between the degree of increase and the $V_{c}$ could be found.

If the patients with ASD are grouped according to the presence of conditions leading to increased pulmonary venous pressure (Table III), it is found that $V_{c}$ is significantly $(p<0.005)$ elevated in those with such complicating lesions (on the average 225 per cent of predicted, as compared with 160 per cent in the uncomplicated group). In the small number of these patients with increased $\dot{Q}_{\mathbf{P}}$ in whom a comparison could be made on the basis of wedge pressure under or over 10 $\mathrm{mm} \mathrm{Hg}$, the $\mathrm{V}_{\mathrm{c}}$ averaged more in those with an elevated pressure, although this difference was not

\footnotetext{
${ }^{6}$ In one patient with a normal $\dot{Q}_{\mathrm{P}}$ (Patient 30 ), DLco was $>2$ SD's above the predicted value; at least part of this increase was on the basis of a markedly elevated hemoglobin concentration.
}

TABLE III

Comparison of groups of patients with increased pulmonary blood flow

\begin{tabular}{|c|c|c|c|c|c|c|c|c|c|}
\hline & \multirow[b]{2}{*}{ Patients } & \multirow[b]{2}{*}{$\begin{array}{l}\text { No. of } \\
\text { cases }\end{array}$} & \multirow[b]{2}{*}{ TLC* } & \multirow[b]{2}{*}{ Dlco* } & \multirow[b]{2}{*}{$\mathrm{DM}^{*}$} & \multirow[b]{2}{*}{$\mathrm{V}_{\mathrm{o}} *$} & \multicolumn{3}{|c|}{ Catheterization data } \\
\hline & & & & & & & $\mathrm{RM}_{\mathrm{M}} \mathbf{R}_{\mathbf{c}}$ & $\dot{\mathrm{Q}}_{\mathbf{P}}$ & $\begin{array}{c}\text { Pulmo- } \\
\text { nary } \\
\text { wedge } \\
\text { pressure }\end{array}$ \\
\hline & & & & & & & & $L / m^{2}$ & $\mathrm{~mm} \mathrm{Hg}$ \\
\hline $\begin{array}{l}\text { ASD, without conditions } \\
\text { tending to produce in- } \\
\text { creased pulmonary venous } \\
\text { pressure }\end{array}$ & $1-17$ & 17 & 94 & 143 & 138 & $160 \dagger$ & $0.99 \dagger$ & 11 & 7 \\
\hline $\begin{array}{l}\text { ASD, with conditions } \\
\text { tending to produce in- } \\
\text { creased pulmonary venous } \\
\text { pressure }\end{array}$ & $18-21$ & 4 & 83 & 152 & 126 & $225 \dagger$ & $1.67 \dagger$ & 8 & 12 \\
\hline $\begin{array}{l}\text { Increased } \dot{Q}_{\mathrm{p}} \\
\overline{\mathrm{P}}_{\mathrm{c}} \leq 10 \mathrm{~mm} \mathrm{Hg}\end{array}$ & $\begin{array}{l}1,5,11,14 \\
19,22,23 \ddagger\end{array}$ & 7 & 92 & 135 & 133 & 150 & $0.97 \S$ & 11 & 6 \\
\hline $\begin{array}{l}\text { Increased } \dot{\mathrm{Q}}_{\mathrm{p}} \\
\overline{\mathrm{P}}_{\mathrm{c}}>10 \mathrm{~mm} \mathrm{Hg}\end{array}$ & $6,18,21,24 \ddagger$ & 4 & 88 & 129 & 107 & 197 & $1.72 \S$ & 10 & 13 \\
\hline
\end{tabular}
TLC.

* TLC as per cent of predicted on the basis of height; DLCo, DM, $\mathrm{V}_{\mathrm{c}}$ as per cent of predicted on the basis of actual test. $\dagger$ Significant difference $(\mathrm{p}<0.005)$ between the averages for Patients 1-17 and for Patients 8-21 using Student's $t$

$\ddagger$ Only patients whose cardiac catheterization was performed within 20 days of the pulmonary studies have been included in these two groups.

$\S$ Significant difference $(p<0.025)$ between the averages for cases with low and with high wedge pressures. 


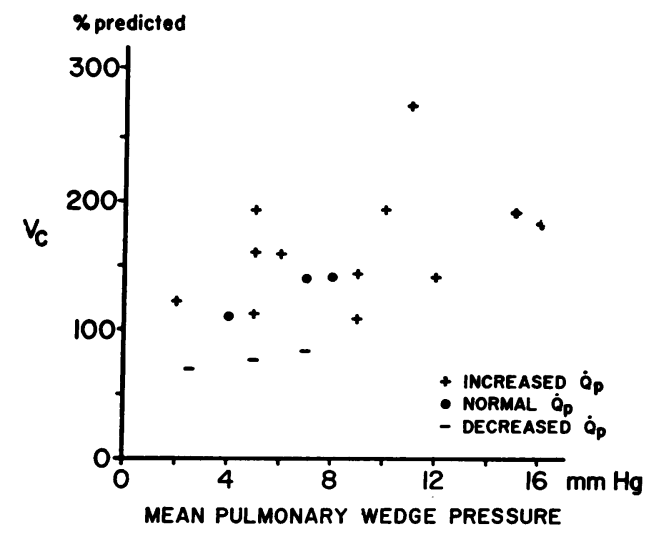

Fig. 4. Pulmonary capillary blood volume ( $\left.\mathrm{V}_{\mathrm{c}}\right)$ VS MEAN PULMONARY ARTERY WEDGE PRESSURE IN THE 18 PATIENTS WITH CONGENITAL HEART DISEASE WHO WERE CATHETERIZED WITHIN 20 DAYS OF THE DIFFUSION STUDIES. $V_{c}$ 's are expressed as per cent of the value predicted on the basis of the patient's actual total lung capacity (6). Pulmonary blood flow $\left(\dot{Q}_{\mathrm{P}}\right)$ was considered increased if more than $5 \mathrm{~L} / \mathrm{min} / \mathrm{m}^{2}$ and decreased if less than 3 $\mathrm{L} / \mathrm{min} / \mathrm{m}^{2}$. The significant $(\mathrm{p}<0.05)$ trend toward increasing $V_{c}$ with increasing wedge pressure is apparent. (Chi square test was used to compare patients with wedge pressures above and below $10 \mathrm{~mm} \mathrm{Hg}$.)

significant. When the $\mathrm{V}_{c}$ 's are plotted (Figure 4) against wedge pressures for all patients catheterized within 20 days of the pulmonary studies, a significant $(\mathrm{p}<0.05)$ trend toward increasing $\mathrm{V}_{\mathrm{c}}$ with increasing wedge pressure is apparent. It is also shown in Figure 4 that even when the wedge pressures were similar, patients with low pulmonary blood flow showed smaller $\mathrm{V}_{\mathrm{c}}$ 's.

In group $I, D M$ is not increased as much as $V_{c}$, and hence $R_{M} / R_{c}$ is on the average significantly $(\mathrm{p}<0.001)$ greater than in normal subjects $(1.14 \pm 0.39$ vs $0.81 \pm 0.17)(6)$. The highest values of $R M / R_{c}$ were found in patients with the highest wedge pressures (Table III and Figure 5).

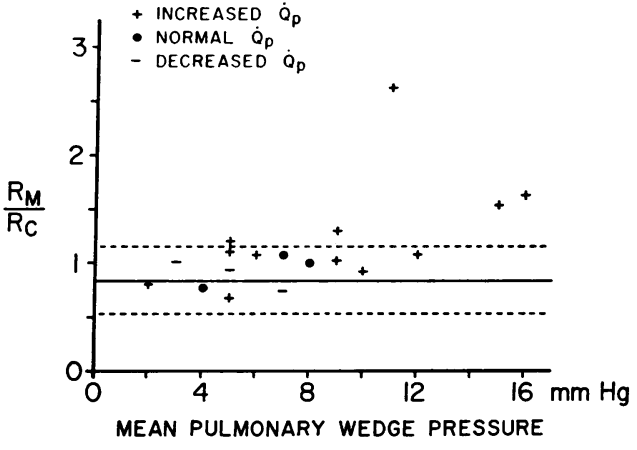

Fig. 5. The Ratio of the MEMbrane to intracapilLARY RESISTANCE TO DIFFUSION $\left(\mathrm{RM}_{\mathrm{M}} / \mathrm{R}_{\mathrm{C}}\right)$ VS MEAN PULMONARY WEDGE PRESSURE. The three lines represent the average and approximately 2 standard deviations around the average for normal subjects (6). Pulmonary blood flow $\left(\dot{Q}_{\mathrm{P}}\right)$ was considered increased if more than 5 $\mathrm{L} / \mathrm{min} / \mathrm{m}^{2}$ and decreased if less than $3 \mathrm{~L} / \mathrm{min} / \mathrm{m}^{2}$. The trend toward increasing membrane resistance relative to the intracapillary resistance with increasing wedge pressure is shown.

In group II the $\mathrm{Rm} / \mathrm{R}_{\mathrm{c}}$ ratio is normal (0.82).

Patient 12 with an ASD was studied during exercise to see if this procedure might further increase the pulmonary capillary blood volume. On moderate exercise this patient's $\mathrm{DL}_{\mathrm{CO}}$ increased from 149 per cent of predicted to 218 per cent, DM from 109 to 165 per cent, and $V_{c}$ from 186 to 245 per cent. These increases with exercise, when expressed as percentage of the control values, were similar to those found for two normal adults who were subjected to approximately the same exercise load (Table IV).

In ten patients diffusion studies were repeated at least 3 months after surgical correction of their cardiac malformation (Table $\mathrm{V}$ ). In the eight patients with ASD or VSD, DL $L_{\mathbf{c o}}$, DM and $\mathrm{V}_{\mathbf{c}}$ decreased on the average to within normal limits

TABLE IV

Effect of exercise on diffusion studies *

\begin{tabular}{|c|c|c|c|c|c|c|c|c|c|c|}
\hline \multirow[b]{2}{*}{ Subject } & \multirow[b]{2}{*}{ Age } & \multirow[b]{2}{*}{ Diagnosis } & \multicolumn{2}{|c|}{$\begin{array}{l}\text { No. of } \\
\text { determin. }\end{array}$} & \multirow[b]{2}{*}{ Exercise } & \multirow{2}{*}{$\begin{array}{l}\text { Heart } \\
\text { rate }\end{array}$} & \multirow[b]{2}{*}{ Dlcot } & \multirow[b]{2}{*}{ DM } & \multirow[b]{2}{*}{$V_{c}$} & \multirow[b]{2}{*}{$\mathbf{R M} / \mathbf{R}_{\mathbf{0}}$} \\
\hline & & & Rest & Exercise & & & & & & \\
\hline & $y r s$ & & & & $k g-m / \min$ & & & & & \\
\hline GB & 32 & Normal & 1 & 3 & 840 & +113 & +28 & +8 & +45 & +40 \\
\hline DC & 41 & Normal & 3 & 2 & 1,000 & +107 & +21 & +14 & +28 & +12 \\
\hline 12 & 26 & ASD & 4 & $\overline{1}$ & 870 & +87 & +46 & +51 & +32 & -6 \\
\hline
\end{tabular}

* Change during exercise expressed as per cent variation from resting values.

$\dagger$ DLco calculated for $120 \mathrm{~mm} \overrightarrow{\mathrm{P}} \mathrm{c}_{\mathrm{or}}$. 
TABLE V

Pre- and postoperative studies

\begin{tabular}{|c|c|c|c|c|c|c|c|}
\hline $\begin{array}{l}\text { Patient } \\
\text { no. }\end{array}$ & Diagnosis & Time of study & TLC & Dlco & $\mathrm{DM}^{*}$ & $\mathrm{~V}_{\mathrm{c}} *$ & $\mathrm{RM} / \mathrm{R}_{\mathrm{c}}$ \\
\hline \multicolumn{8}{|c|}{$\begin{array}{l}L \\
\text { Group I : increased } \dot{Q}_{p}\end{array}$} \\
\hline 2 & ASD & $\begin{array}{l}\text { Pre-op. } \\
10 \text { mos postop. } \\
\text { Difference }\end{array}$ & $\begin{array}{l}2.05 \\
2.16\end{array}$ & $\begin{array}{r}114 \\
78 \\
-36\end{array}$ & $\begin{array}{r}115 \\
81 \\
-34\end{array}$ & $\begin{array}{r}131 \\
96 \\
-35\end{array}$ & $\begin{array}{r}1.13 \\
1.13 \\
0\end{array}$ \\
\hline 3 & ASD & $\begin{array}{l}\text { Pre-op. } \\
4 \text { mos postop. }\end{array}$ & $\begin{array}{l}2.36 \\
2.48\end{array}$ & $\begin{array}{r}146 \\
97 \\
-49\end{array}$ & $\begin{array}{r}145 \\
96 \\
-49\end{array}$ & $\begin{array}{r}187 \\
110 \\
-77\end{array}$ & $\begin{array}{r}1.19 \\
1.06 \\
-0.13\end{array}$ \\
\hline 6 & ASD & $\begin{array}{l}\text { Pre-op. } \\
4 \text { mos postop. } \\
\text { Difference }\end{array}$ & $\begin{array}{l}4.53 \\
4.69\end{array}$ & $\begin{array}{r}120 \\
102 \\
-18\end{array}$ & $\begin{array}{r}104 \\
84 \\
-20\end{array}$ & $\begin{array}{l}141 \\
134 \\
-7\end{array}$ & $\begin{array}{r}1.08 \\
1.18 \\
+0.10\end{array}$ \\
\hline 7 & ASD & $\begin{array}{l}\text { Pre-op. } \\
6 \text { mos postop. } \\
\text { Difference }\end{array}$ & $\begin{array}{l}2.28 \\
2.14\end{array}$ & $\begin{array}{r}161 \\
133 \\
-28\end{array}$ & $\begin{array}{r}183 \\
163 \\
-20\end{array}$ & $\begin{array}{r}171 \\
116 \\
-55\end{array}$ & $\begin{array}{r}0.91 \\
0.58 \\
-0.33\end{array}$ \\
\hline 10 & ASD & $\begin{array}{l}\text { Pre-op. } \\
10 \text { mos postop. } \\
\text { Difference }\end{array}$ & $\begin{array}{l}5.93 \\
5.92\end{array}$ & $\begin{array}{r}183 \\
100 \\
-83\end{array}$ & $\begin{array}{r}141 \\
135 \\
-6\end{array}$ & $\begin{array}{r}156 \\
71 \\
-85\end{array}$ & $\begin{array}{r}0.83 \\
0.48 \\
-0.35\end{array}$ \\
\hline 11 & ASD & $\begin{array}{l}\text { Pre-op. } \\
4 \text { mos postop. } \\
\text { Difference }\end{array}$ & $\begin{array}{l}4.36 \\
4.11\end{array}$ & $\begin{array}{r}144 \\
120 \\
-24\end{array}$ & $\begin{array}{l}120 \\
122 \\
+2\end{array}$ & $\begin{array}{r}193 \\
120 \\
-73\end{array}$ & $\begin{array}{r}1.20 \\
0.79 \\
-0.41\end{array}$ \\
\hline 12 & ASD & $\begin{array}{l}\text { Pre-op. } \\
4 \text { mos postop. } \\
\text { Difference }\end{array}$ & $\begin{array}{l}6.89 \\
6.60\end{array}$ & $\begin{array}{r}149 \\
113 \\
-36\end{array}$ & $\begin{array}{r}109 \\
86 \\
-23\end{array}$ & $\begin{array}{r}186 \\
139 \\
-47\end{array}$ & $\begin{array}{r}1.20 \\
1.20 \\
0\end{array}$ \\
\hline 22 & VSD & $\begin{array}{l}\text { Pre-op. } \\
5 \text { mos postop. } \\
\text { Difference }\end{array}$ & $\begin{array}{l}3.17 \\
3.21\end{array}$ & $\begin{array}{r}132 \\
92 \\
-40\end{array}$ & $\begin{array}{l}126 \\
120 \\
-6\end{array}$ & $\begin{array}{r}159 \\
91 \\
-68\end{array}$ & $\begin{array}{r}1.08 \\
0.64 \\
-0.44\end{array}$ \\
\hline Aver & & $\begin{array}{l}\text { Pre-op. } \\
\text { Postop. } \\
\text { Difference }\end{array}$ & $\begin{array}{r}3.95 \\
3.91 \\
-0.04\end{array}$ & $\begin{array}{r}144 \\
104 \\
-40\end{array}$ & $\begin{array}{r}130 \\
110 \\
-20\end{array}$ & $\begin{array}{r}166 \\
110 \\
-56\end{array}$ & $\begin{array}{r}1.08 \\
0.88 \\
-0.20\end{array}$ \\
\hline \multicolumn{3}{|c|}{$\begin{array}{l}\text { Significance of difference } \\
\text { of average of pre- and post- } \\
\text { operative values } \dagger p=\end{array}$} & & $<0.001$ & $<0.025$ & $<0.001$ & $<0.05$ \\
\hline \multicolumn{8}{|c|}{ Group II : decreased $\dot{Q}_{p}$} \\
\hline 25 & PS & $\begin{array}{l}\text { Pre-op. } \\
5 \text { mos postop. } \\
\text { Difference }\end{array}$ & $\begin{array}{l}2.24 \\
2.07\end{array}$ & $\begin{array}{l}108 \\
100 \\
-8\end{array}$ & $\begin{array}{r}125 \\
104 \\
-21\end{array}$ & $\begin{array}{r}100 \\
94 \\
-6\end{array}$ & $\begin{array}{r}0.73 \\
0.87 \\
+0.14\end{array}$ \\
\hline 26 & PS & $\begin{array}{l}\text { Pre-op. } \\
3 \text { mos. postop. } \\
\text { Difference }\end{array}$ & $\begin{array}{l}2.95 \\
2.65\end{array}$ & $\begin{array}{r}78 \\
71 \\
-7\end{array}$ & $\begin{array}{r}75 \\
60 \\
-15\end{array}$ & $\begin{array}{r}77 \\
85 \\
+8\end{array}$ & $\begin{array}{r}0.94 \\
1.37 \\
+0.43\end{array}$ \\
\hline \multicolumn{2}{|c|}{ Average } & $\begin{array}{l}\text { Pre-op. } \\
\text { Postop. } \\
\text { Difference }\end{array}$ & $\begin{array}{l}2.59 \\
2.36\end{array}$ & $\begin{array}{r}93 \\
86 \\
-7\end{array}$ & $\begin{array}{r}100 \\
82 \\
-18\end{array}$ & $\begin{array}{r}88 \\
89 \\
+1\end{array}$ & $\begin{array}{r}0.83 \\
1.12 \\
+0.29\end{array}$ \\
\hline
\end{tabular}

* Expressed as per cent of the value predicted on the basis of TLC.

$\dagger$ Paired (Student's $t$ test) used for calculation of significance.

indicating that the changes, at least in most cases, were apparently reversible. In the two patients operated on for pulmonic stenosis there were no significant changes, although both showed slight decreases in $\mathrm{DL}_{\mathrm{Co}}$ and $\mathrm{Dm}$ and an increase in the $\mathrm{RM}_{\mathrm{M}} / \mathrm{R}_{\mathrm{c}}$ ratio.

\section{DISCUSSION}

The significance and limitations of the measurements of $\mathrm{DL}_{\mathrm{CO}}$, $\mathrm{D}_{\mathrm{M}}$ and $\mathrm{V}_{\mathrm{c}}$ have been recently reviewed (17) and the application of the techniques to normal children has been reported (6). The interpretation of diffusion studies involves ques- 
tionable assumptions in patients with abnormal air distribution. Abnormal distribution occurs in patients with pulmonary congestion (18); however, on the basis of physical and roentgenological examinations, normal residual volume to TLC ratios, and normal timed vital capacity measurements, no or at most only minor distribution abnormalities were thought to be present in this series of patients with congenital heart disease.

- In patients with a left-to-right shunt, varying amounts of blood recirculate through the lungs during the 10 -second breath-holding period. This would result in an increased back pressure of $\mathrm{CO}$ which would reduce the $\mathrm{DL}_{\mathrm{CO}}$. If a correction for this factor had been possible, $\mathrm{DM}_{\mathrm{M}}, \mathrm{V}_{\mathrm{c}}$ and the $\mathrm{Rm} / \mathrm{R}_{\mathrm{c}}$ ratio in patients with left-to-right shunts would have been even greater and the validity of the conclusions of the study would have been strengthened.

The values for the constant $\theta$ have been determined by Roughton, Forster and Cander $(4,5)$ in hemoglobin solutions made from the red cells of normal adults, and there may be factors, unknown at present, which affect these values for the hemoglobin of abnormal individuals. The effect on $\theta$ of varying $\mathrm{P}_{\mathrm{CO}_{2}}$ is not known, but the addition of as much as 10 per cent $\mathrm{CO}_{2}$ to the inspired gas produces only minor changes in the 10-second $\mathrm{DL}_{\mathrm{CO}}$ (19). Furthermore, $\mathrm{DL}_{\mathrm{CO}}$ does not change significantly with changes in blood $\mathrm{pH}(20)$.

One additional limitation in the interpretation of these diffusion studies in patients with congenital heart disease results from the fact that it is not known whether the relationship between the hematocrit of systemic and pulmonary capillary blood is similar in normal subjects and in those with congenital heart disease.

In spite of the above limitations, it is felt that the studies in patients with congenital heart disease are probably comparable to those in normal persons. Since, for the most part, the differences for many of the individual patients and particularly for certain groups are relatively large, it is thought that certain conclusions are warranted.

A number of other authors has reported diffusion studies in patients with congenital heart disease. Auchincloss, Gilbert and Eich (21) and Bedell (22) have found increases in $\mathrm{DL}_{\mathrm{co}}$ in several cases of VSD and ASD; normal or only slightly decreased values were found with normal or decreased $\dot{Q}_{\mathbf{p}}$. However, in no cases reported or in the present series has $\mathrm{DL}_{\mathrm{Co}}$ been decreased enough to suggest even minimal diffusion difficulties. Rankin and Callies (23) found increased $\mathrm{DL}_{\mathrm{CO}}, \mathrm{DM}$ and $\mathrm{V}_{\mathrm{c}}$ in 12 patients with conditions associated with increased $\dot{Q}_{\mathbf{P}}$ when pulmonary artery hypertension was absent. Thus, these reports are consistent with the present findings of significant increases in $\mathrm{DL}_{\mathrm{CO}}, \mathrm{DM}_{\mathrm{M}}$ and $\mathrm{V}_{\mathrm{c}}$ in patients with an increased pulmonary artery wedge pressure and $\dot{Q}_{\mathbf{P}}$. The results are in accord with anatomical observations in at least one cause of pulmonary vascular distention, mitral stenosis, in which Parker and Weiss (24) reported pulmonary capillaries which were dilated and possibly increased in number or length or in both. In the relatively few patients studied in the present series who had normal or decreased $\dot{Q}_{\mathrm{P}}$ 's, the lowest $V_{c}$ 's were associated with the lowest $\dot{Q}_{p}$ 's.

On the basis of the postoperative studies, it would appear that increases in $D_{M}$ and $V_{c}$, even though presumably present for many years, are usually reversible. In addition, the response to exercise of the patient with a large ASD suggests that, even after years of subjection to increased $\dot{Q}_{P}$, the capillary bed may increase in size still further.

Mechanisms regulating the size of the pulmonary capillary bed are not entirely clear. However, since no contractile (muscular) elements can be demonstrated in the capillaries, the transmural pressure and the elastic characteristics of the capillary walls must be the locally determining factors. Not only may the pulmonary capillary volume be increased by the opening of capillaries which have been previously closed until their critical opening pressure has been reached $(25,26)$, but also increases in pressure may further distend capillaries which are already open. In contrast to these local, passive responses of the pulmonary capillaries to changes in pressure, an active regulation of the capillary volume may result from fluctuations in the resistance of the pre- or postcapillary blood vessels.

A number of studies of lung diffusion has attempted to clarify the physiological factors which lead to changes in pulmonary capillary blood volume. In isolated cat lungs Rosenberg and Forster (27) found that increases in intracapillary pres- 
sure were associated with increases in $\mathrm{V}_{\mathbf{c}}$ as measured by diffusion techniques. In normal subjects and patients with varying hemodynamic conditions a variety of results, often contradictory, has been reported (28-33). The data are difficult to interpret because some of the studies have used the steady state carbon monoxide diffusion technique, and the effect of changes in ventilation per se could not be accurately determined. In addition part or all of the hemodynamic changes have been inferred from other studies of similar situations or from indirect measurements. Nevertheless, the large increases in $\mathrm{DL}_{\mathrm{CO}}$ and $\mathrm{V}_{\mathrm{c}}(15,20$, 29 ) with only minor changes in wedge pressure (34) reported relatively consistently in exercise studies, suggest that there is some active regulation of the resistance of the pre- or post-pulmonary capillary vessels which affects the volume of the pulmonary capillaries.

An irreversible type of change in the resistance of the pre-capillary vessels which may influence $\mathrm{V}_{\mathrm{c}}$ is illustrated by patients with pulmonary arterial obstruction. In such patients, although histological examination of the capillaries has indicated no structural changes which might limit distensibility (35), $V_{c}$ may be normal or reduced even when the pulmonary artery pressure is markedly elevated. Patient 34 would appear to represent such a situation.

In the present study it seems clear that the increase in $V_{c}$ in most patients with left-to-right shunts is secondary to an increase in $\dot{Q}_{P}$ and occasionally to an increase in capillary pressure. ${ }^{7}$ The importance of capillary pressure as a passive regulating factor is emphasized by the observation that patients with the greatest increase in $V_{c}$ had also the highest wedge pressures. The failure to find a more exact correlation between wedge pressure levels and $V_{c}$ is probably based on the variability of the measurements, and lability of circulation and pulmonary function.

Theoretically DM is dependent upon: 1) the

${ }^{7}$ Although it is recognized that the mean pulmonary artery wedge pressure may not be identical to the capillary pressure, the two are closely related when pulmonary arterial obstruction is absent (36). Since only 3 of the 34 patients in the present series had evidence of vascular obstruction, it has been assumed in the discussion which follows that wedge pressure values are representative of capillary pressures. area of the diffusing surface of the pulmonary capillaries, 2) the thickness of the membrane, 3) the specific diffusivity, and 4) the solubility of $\mathrm{CO}$ in the tissues of the pulmonary membrane (37). No information is available on possible changes of the last two factors in health or disease, but great variations are unlikely. The capillary volume/surface area ratio is largely a matter of speculation. The alveolar capillaries have been described as a fine network mesh (38), but detailed information on the morphology in normal and abnormal conditions and at various blood flows and lung distentions is lacking.

In its simplest model the pulmonary capillary network could be considered to be composed of a number of cylindrical segments. In such a model, the ratio of the volume to the area of the curved surface would remain constant when the length of the cylinders increased, and would increase if the radii increased. The latter situation would correspond to an increase of the $\mathrm{RM} / \mathrm{R}_{\mathrm{c}}$ ratio. Other possibilities might also be proposed, but too little information on the geometry of the capillaries is available to make further analysis useful.

The $\mathrm{RM}_{\mathrm{M}} / \mathrm{R}_{\mathrm{c}}$ ratio may also increase if the thickness of the pulmonary membrane increases. An increased $R M / R_{c}$ ratio has been found in several conditions associated with increased $V_{c}$, e.g., in pulmonary congestion (12) and in exercise (15) (Table IV) as well as in our patients with congenital heart disease with or without mitral disease (Table III). Increased or uneven $\mathrm{P}_{\mathrm{CO}}$ gradients caused by augmented velocity of the capillary blood stream could produce an apparent decrease of $D_{M}$ in subjects with high $\dot{Q}_{\mathbf{P}}$, but it seems unlikely that this would appreciably affect the results since the $\mathrm{P}_{\mathrm{CO}}$ equilibration in the pulmonary capillaries is presumably almost instantaneous (17).

Alterations of the volume/surface area ratio and/or increased thickness of the pulmonary capillary membrane might explain the mild increase of the $R M / R_{c}$ ratio observed in the majority of the patients. The second possibility is supported by microscopic findings in lungs of patients with mitral stenosis (24). However, further studies are necessary to elucidate the nature of the anatomic and functional changes of the pulmonary capillary membrane in other types of heart disease. 
The postoperative studies indicate that in patients with high $\dot{Q}_{P}$ the re-establishment of normal hemodynamic conditions is usually followed by a return toward normal of the pulmonary capillary bed. However, since none of the reported patients preoperatively had greatly elevated $R M / R_{e}$ ratios, this reversal might not apply to patients with markedly altered pulmonary membranes.

\section{SUMMARY}

Studies of total lung diffusing capacity $\left(\mathrm{DL}_{\mathrm{CO}}\right)$, diffusing capacity of the pulmonary membrane (Dм) and pulmonary capillary blood volume $\left(\mathrm{V}_{\mathrm{c}}\right)$, using the 10-second carbon monoxide technique, have been made in 34 patients with congenital heart disease. Patients with increased pulmonary blood flow ( $\dot{Q}_{\mathbf{p}}$ ) or increased mean pulmonary wedge pressure or both tended to have a significant increase in $\mathrm{DL}_{\mathrm{CO}}, \mathrm{DM}_{\mathrm{M}}$ and $\mathrm{V}_{\mathrm{c}}$. $\mathrm{Pa}$ tients with normal or decreased $\dot{Q}_{\mathbf{P}}$ had normal or slightly decreased $V_{c}$ and Dm values. When patients with increased $\dot{Q}_{\mathbf{P}}$ had surgical correction of their malformation, the $\mathrm{DL}_{\mathrm{co}}, \mathrm{Dm}_{\mathrm{m}}$ and $\mathrm{V}_{\mathrm{c}}$ usually returned to normal. Exercise studies in one patient with a left-to-right shunt and a high $\mathrm{V}_{\mathrm{c}}$ suggested that the pulmonary capillaries may increase in volume still further. The possible mechanisms underlying the changes in diffusion and its components are discussed.

\section{REFERENCES}

1. Roughton, F. J. W. The average time spent by the blood in the human lung capillary and its relation to the rates of $\mathrm{CO}$ uptake and elimination in man. Amer. J. Physiol. 1945, 143, 621.

2. Forster, R. E., Roughton, F. J. W., Cander, L., Briscoe, W. A., and Kreuzer, F. Apparent pulmonary diffusing capacity for $\mathrm{CO}$ at varying alveolar $\mathrm{O}_{2}$ tensions. J. appl. Physiol. 1957, 11, 277.

3. Forster, R. E., Roughton, F. J. W., Kreuzer, F., and Briscoe, W. A. Photocolorimetric determination of rate of uptake of $\mathrm{CO}$ and $\mathrm{O}_{2}$ by reduced human red cell suspensions at $37^{\circ}$ C. J. appl. Physiol. 1957, 11, 260.

4. Roughton, F. J. W., Forster, R. E., and Cander, L. Rate at which carbon monoxide replaces oxygen from combination with human hemoglobin in solution and in the red cell. J. appl. Physiol. 1957, 11, 269.

5. Roughton, F. J. W., and Forster, R. E. Relative importance of diffusion and chemical reaction rates in determining rate of exchange of gases in the human lung, with special reference to true diffusing capacity of pulmonary membrane and 'volume of blood in the lung capillaries. J. appl. Physiol. 1957, 11, 290.

6. Bucci, G., Cook, C. D., and Barrie, H. Studies of respiratory physiology in children, V. Total lung diffusion, diffusing capacity of pulmonary membrane and pulmonary capillary blood volume in normal subjects from 7 to 40 years of age. J. Pediat. 1961, 58, 820.

7. Rudolph, A. M., and Cayler, G. G. Cardiac catheterization in infants and children. Ped. Clin. N. Amer. 1958, 5, 907.

8. Helliesen, P. J., Cook, C. D., Friedlander, L., and Agathon, S. Studies of respiratory physiology in children. I. Mechanics of respiration and lung volumes in 85 normal children 5 to 17 years of age. Pediatrics 1958, 22, 80.

9. Forster, R. E., Fowler, W. S., Bates, D. V., and Van Lingen, B. The absorption of carbon monoxide by the lungs during breathholding. J. clin. Invest. 1954, 33, 1135.

10. Forster, R. E., Cohn, J. E., Briscoe, W. A., Blakemore, W. S., and Riley R. L. A modification of the Krogh $\mathrm{CO}$ breath holding technique for estimating the diffusing capacity of the lung; a comparison with three other methods. J. clin. Invest. 1955, 34, 1417.

11. Ogilvie, C. M., Forster, R. E., Blakemore, W. S., and Morton, J. W. A standardized breath holding technique for the clinical measurement of the diffusing capacity of the lung for carbon monoxide. J. clin. Invest. 1957, 36, 1.

12. McNeill, R. S., Rankin, J., and Forster, R. E. The diffusing capacity of the pulmonary membrane and the pulmonary capillary blood volume in cardiopulmonary disease. Clin. Sci. 1958, 17, 465.

13. Hepper, N. G. G., Fowler, W. S., and Helmholz, H. F., Jr. Relationship of height to lung volume in healthy men. Dis. Chest. 1960, 37, 314.

14. Donald, K. W., Bishop, J. M., Cumming, G., and Wade, O. L. The effect of exercise on the cardiac output and circulatory dynamics of normal subjects. Clin. Sci. 1955, 14, 37.

15. Johnson, R. L., Jr., Spicer, W. S., Bishop, J. M., and Forster, R. E. Pulmonary capillary blood volume, flow and diffusing capacity during exercise. J. appl. Physiol. 1960, 15, 893.

16. Bengtsson, E. The working capacity in normal children, evaluated by submaximal exercise on the bicycle ergometer and compared with adults. Acta med. scand. 1956, 154, 91.

17. Forster, R. E. Exchange of gases between alveolar air and pulmonary capillary blood: Pulmonary diffusing capacity. Physiol. Rev. 1957, 37, 391.

18. Turino, G. M., and Fishman, A. P. The congested lung. J. chron. Dis. 1959, 9, 510.

19. Rankin, J., McNeill, R. S., and Forster, R. E. Influence of increased alveolar $\mathrm{CO}_{2}$ tension on pul- 
monary diffusing capacity for CO in man. J. appl. Physiol. 1960, 15, 543.

20. Ross, J. C., Frayser, R., and Hickam, J. B. A study of the mechanism by which exercise increases the pulmonary diffusing capacity for carbon monoxide. J. clin. Invest. 1959, 38, 916.

21. Auchincloss, J. H., Jr., Gilbert, R., and Eich, R. H. The pulmonary diffusing capacity in congenital and rheumatic heart disease. Circulation 1959, 19, 232.

22. Bedell, G. N. A comparison of pulmonary diffusing capacity in patients with atrial and ventricular septal defects (abstract). J. Lab. clin. Med. 1958, 52, 791.

23. Rankin, J., and Callies, Q. C. The influence of atrial and ventricular septal defects on the capillary bed of the lung and on the diffusion characteristics of the pulmonary membrane (abstract). J. Lab. clin. Med. 1958, 52, 937.

24. Parker, F., Jr., and Weiss, S. The nature and significance of the structural changes in the lungs in mitral stenosis. Amer. J. Path. 1936, 12, 573.

25. Burton, A. C. On the physical equilibrium of small blood vessels. Amer. J. Physiol. 1951, 164, 319.

26. Nichol, J., Girling, F., Jerrard, W., Claxton, E. B., and Burton, A. C. Fundamental instability of the small blood vessels and critical closing pressures in vascular beds. Amer. J. Physiol. 1951, 164, 330.

27. Rosenberg, E., and Forster, R. E. Changes in diffusing capacity of isolated cat lungs with blood pressure and flow. J. appl. Physiol. 1960, 15, 883.

28. Lewis, B. M., Forster, R. E., and Beckman, E. L. Effect of inflation of a pressure suit on pulmonary diffusing capacity in man. J. appl. Physiol. 1958, $12,57$.

29. Lewis, B. M., Lin, T-H, Noe, F. E., and Komisaruk,
R. The measurement of pulmonary capillary blood volume and pulmonary membrane diffusing capacity in normal subjects; the effects of exercise and position. J. clin. Invest. 1958, 37, 1061.

30. Turino, G. M., Brandfonbrener, M., and Fishman, A. P. The effect of changes in ventilation and pulmonary blood flow on the diffusing capacity of the lung. J. clin. Invest. 1959, 38, 1186.

31. Lewis, B. M., McElroy, W. T., Hayford-Welsing, E. J., and Samberg, L. C. The effects of body position, ganglionic blockade and norepinephrine on the pulmonary capillary bed. J. clin. Invest. 1960, 39, 1345.

32. Ross, J. C., Lord, T. H., and Ley, G. D. Effect of pressure-suit inflation on pulmonary-diffusing capacity. J. appl. Physiol. 1960, 15, 843.

33. Johnson, R. L., Jr., Stein, M. K., and Kimbel, P. Pulmonary capillary blood flow and diffusing capacity before and after successful treatment for hyperthyroidism. Fed. Proc. 1958, 17, 81.

34. Dexter, L., Whittenberger, J. L., Haynes, F. W., Goodale, W. T., Gorlin, R., and Sawyer, C. G. Effect of exercise on circulatory dynamics of normal individuals. J. appl. Physiol. 1951, 3, 439.

35. Craig, J. M. Personal communication.

36. Gordon, A. J., Braunwald, E., Ravitch, M. M., Amram, S. S., Lasser, R. P., Moscovitz, H. L., and Sapin, S. O. Simultaneous pressure pulses in the human left atrium, ventricle and aorta (prelim. communic.). Circulat. Res. 1954, 2, 432.

37. Forster, R. E. The pulmonary capillary bed: Volume, area and diffusing characteristics in Pulmonary Circulation, W. Adams and I. Veith, Eds. New York and London, Grune \& Stratton, 1959, pp. $45-56$.

38. Miller, W. S. The Lung, 2nd ed. Springfield, Ill. Charles C Thomas, 1950, p. 76. 